\title{
AC 2010-1109: CHANGING HIGH SCHOOL STEM TEACHER BELIEFS AND EXPECTATIONS ABOUT ENGINEERING LEARNING AND INSTRUCTION
}

\section{Mitchell Nathan, University of Wisconsin, Madison}

Professor Mitchell Nathan, PhD and BSEE, is currently Chair of the Learning Sciences program at the University of Wisconsin-Madison, and a founding officer of the International Society of the Learning Sciences (ISLS). Dr. Nathan studies the cognitive, embodied, and social processes involved in learning and teaching mathematics, science and engineering in classrooms and the laboratory, using analysis of discourse, survey and assessment instruments, and experimental design. Dr. Nathan examines teacher beliefs about student learning and the influences of the expert blind spot, where high content knowledge in teachers shapes their expectations of novices' conceptual development. Dr. Nathan also examines students' inventions of mathematical representations and strategies for reasoning about quantity and pattern. In the social setting of the classroom, Dr. Nathan explores the nature of collaborative discourse, gesture and action, and representations during learning and instruction. Dr. Nathan has secured over $\$ 12 \mathrm{M}$ in external research funds and has over 80 peer reviewed publications in educational research and cognitive science, as well as over 100 scholarly presentations to US and international audiences.

\section{Amy Atwood, University of Wisconsin, Madison}

Amy K. Atwood a Quantitative Methods graduate student in the Department of Educational Psychology at the University of Wisconsin-Madison. Her research has primarily focused on the appropriate use of statistical methods, particularly those involving preliminary tests of significance.

\section{Amy Prevost, University of Wisconsin, Madison}

Amy Prevost is a graduate student in Education Leadership and Policy Analysis at the University of Wisconsin-Madison. Her research has focused on the STEM career pipeline, especially related to engineering and engineering education and biotechnology.

\section{Allen Phelps, University of Wisconsin, Madison}

L. Allen Phelps is Professor of Educational Leadership \& Policy Analysis, and Director of the Center on Education and Work at the University of Wisconsin-Madison. Over the past two decades, his research, teaching, and public service work has focused on the interaction between the education and economic sectors with particular attention to policy initiatives, equity issues, and professional development. 


\title{
Changing High School STEM Teachers' Beliefs and Expectations about Engineering Learning and Instruction
}

\begin{abstract}
In response to increased interest in engineering education at the high school level and the availability of new funding for pre-college STEM programs, a growing number of high school teachers are participating in professional development activities in engineering. Education research has demonstrated that meaningful and sustainable change in instruction is based on knowledge of teachers' judgments, beliefs and expectations about learning and instruction. Yet little is known about the "engineering teaching culture" and there are few methods in place to reliably measure teachers' views or how those views are influenced by participation in professional development programs. This study documented teachers' views and expectations regarding engineering learning and instruction, and measured the impact that professional development training for pre-college engineering had on these beliefs. We examined this in the context of a specific, well-regarded, pre-college engineering program, Project Lead the Way (PLTW). We measured teachers' views before and after training and teaching their first PLTW course, as compared to changes observed with a control group of STEM teachers. Some preexisting differences reached statistical significance: Prospective PLTW teachers were more likely than control teachers to identify sources of support for engineering in their schools, report that science and math concepts were integrated with engineering instruction; and to support greater access to engineering. Over time, teachers from both groups were significantly less inclined to use students' interests and backgrounds to shape classroom instruction. The primary change attributable specifically to the intervention was the increased belief among newly minted PLTW teachers that they were providing engineering instruction that effectively integrated science and math concepts. While this is seen as desirable and in keeping with current education efforts, the final section examines some of the challenges of implementing effective STEM integration in high school classrooms.
\end{abstract}

\section{The Importance of Studying Teacher Beliefs about Engineering Education}

As U.S. high schools respond to calls for improving student learning in math, science and precollege engineering ${ }^{1}$ and the availability of increased funding opportunities such as Race to the Top, ${ }^{2}$ greater numbers of K-12 educators are participating in STEM (science, technology, engineering and mathematics) professional development activities. Consequently there is a growing need to understand K-12 STEM teachers' knowledge and beliefs, effectiveness and instructional decision making ${ }^{3}$. Education research shows that instructional practice and teacher decision making are influenced by teachers' beliefs about learning and instruction ${ }^{4-8}$. Furthermore, the educational experience for students is dependent on the quality and effectiveness of teachers, more than perhaps any other single alterable factor ${ }^{9-11}$. For example, teachers' views have serious implications for the perceived place and purpose of engineering in the K-12 curriculum, as noted in a recent report from the National Academy of Engineering ${ }^{12}$. Furthermore, as professional development programs in pre-college engineering proliferate, there 
is additional need to understand how teachers' beliefs and expectations about engineering instruction and learning change as teachers learn more about engineering and how to teach it.

There have been recent studies on teacher knowledge, beliefs and instructional practices for engineering education. Yasar and colleagues ${ }^{13}$ surveyed K-12 teachers' knowledge and perceptions of engineers and engineering practice, including: the importance of teaching design, engineering and technology; teachers' familiarity with engineering and design; their perceptions of engineers; and perceived characteristics of engineering practices. The authors argue that understanding teachers' views in this area is a necessary step toward developing long-range plans to better integrate technology and design into K-12 education. Shulman ${ }^{14}$, directing research of the Carnegie Foundation for the Advancement of Teaching, documented how universities prepare students for professional practice in areas of law, nursing, the clergy, and engineering. The "signature pedagogy" for engineering is shown to demonstrate "a lovely juxtaposition between the formal requirements entailed in learning math and science and the creative challenges that accompany "messing with the world"' (p. 11). Yet the editors of Journal of Engineering Education acknowledge there is still little known about the "engineering teaching culture."

To address this growing area of interest and importance, we set out to examine alreadypracticing teachers' beliefs and expectations about engineering instruction and student learning as it occurs at the high school level, and document how these views change as teachers become newly trained to use an engineering education curriculum. We examined teachers' changing beliefs in the context of their initial experiences teaching courses from the Project Lead the Way (PLTW) program. Although some selection bias is inherent in a study of this nature (we are not currently at liberty to assign who will and will not teach PLTW), causal inferences are supported by examining changes in teachers' views before and after their first PLTW course above and beyond those changes exhibited by a control group of STEM teachers who did not participate in the training or teaching of a PLTW course.

\section{Measuring Teacher Beliefs with the Engineering Education Beliefs and Expectations Instrument}

Previous research ${ }^{16}$ has shown the EEBEI-T (pronounced "eebee tee") to be a statistically reliable survey instrument that measures teachers' views as they relate directly to pre-college engineering education, preparation for future studies in engineering, and expectations or success in engineering careers. The EEBEI-T instrument was originally given to 143 high school STEM teachers located in a moderately large urban city in the Midwestern US.

Results show the instrument to contain seven highly reliable constructs ( $\alpha \geq .70)$, with sample means falling midway on the Likert scales. Reliability was replicated with a national sample of STEM teachers $(\mathrm{N}=82)$. Regarding STEM instruction, most teachers report using students' interests, cultural and family backgrounds, and students' prior assessment performance to guide their teaching practices. A minority of teachers reported that they adequately integrate math and science concepts with engineering activities and concepts. 
With regard to engineering preparation, teachers agreed that it takes place in multiple contexts, including academic and technical education courses, as well as home, community and workplace settings. Teachers generally believed that to become an engineer a student must show high academic achievement in their math, science and technology courses. Teachers also believed that having a parent as an engineer increases a student's likelihood of becoming one, as does being male and either white or Asian. However, socio-economic status was not reported as an important consideration by the teachers when determining student preparation using the Likert scale items.

Prior results also showed the EEBIE-T to be sensitive to group differences between teachers who focused primarily on engineering education within career and technical education programs and those teachers in the sample primarily focused on instruction in college preparatory math and science. Statistically significant differences $(p<.05)$ were identified in three areas. First, math and science teachers as a group were less likely to identify sources of support for engineering in their schools than engineering teachers. Second, math and science teachers more strongly supported the view that an engineer needs to show high levels of academic achievement in math, science and technology. Third, engineering teachers were far more likely to agree that their classroom instruction effectively integrates engineering activities with concepts from math and science.

Content validity ${ }^{17}$ of the instrument, sometimes also referred to as "face validity", was also established. First, the survey corroborated the expectation that current and prospective engineering teachers would be more aware of the engineering resources offered and more likely to be in schools that offer such resources. Second, as expected, the survey found that teachers of academically oriented science and math courses that typically serve a college preparatory function rather than providing technical skills will regard excellence in academic performance as paramount to success in engineering.

Having demonstrated the reliability and, to some extent, the validity of the EEBEI-T, the next logical step was to use it to measure changes in teachers' views as a result of becoming an engineering teacher. This would provide insights about the impact that the PLTW professional development programs can have on teachers' views. Such findings contribute to our understanding of the nature of high school engineering instruction and teacher change during a critical aspect of the engineering pathway.

\section{Pre-college engineering education: The Project Lead the Way curriculum and teacher training}

We chose to examine this in the context of a specific, well-regarded, engineering program, Project Lead the Way (PLTW). PLTW is one of the most widely used pre-college engineering curricula in the U.S. The program been adopted by more than 2,700 schools $(2000$ high schools and 700 middle schools ${ }^{18}$, and is present in all 50 states $^{19}$. PLTW was singled out in Rising Above the Gathering Storm ${ }^{1}$ as a model curriculum for providing the kind of rigorous K-12 materials needed to improve math and science learning and increase America's technological talent pool. Thus, findings based on PLTW have far-reaching implications. PLTW is designed to integrate engineering, math, science, and technology into the students' academic program of 
study at the middle and high school levels. The high school program, Pathway to Engineering ${ }^{\mathrm{TM}}$ offers seven high school courses including three one-year foundation courses (Introduction to Engineering Design, Principles of Engineering, and Digital Electronics) as well as specialization courses (Aerospace Engineering, Biotechnical Engineering, Civil Engineering and Architecture, and Computer Integrated Manufacturing). These courses can be used for credit at accredited colleges and universities. In addition, there is an engineering research capstone course, Engineering Design \& Development ${ }^{20}$.

Everyone teaching PLTW courses must attend an extensive professional development program, including training provided by the PLTW network of affiliate colleges and universities, as a precondition to teaching any one of the courses. This training aims to make teachers proficient in project- and problem-based instruction ${ }^{21}$. In addition to hosting summer training institutes and ongoing professional development, national affiliates offer graduate credit for teachers.

A recent international review of research on professional learning for educators by Linda Darling-Hammond and colleagues ${ }^{22}$ report that strategically designed, intensive, and sustained professional learning can have a powerful influence on teacher skills and knowledge and ultimately lead to improvements in student learning. Prevost and colleagues ${ }^{23}$ examined the PLTW teacher professional development training documents, training activities, teacher projects, and teacher self-assessment and self-reflection items. They described it as localized to a twoweek intensive program rich with engineering and math concepts that were often implicitly embedded in the engineering activities. Little, however, was revealed about the impact these training experiences had on teachers' beliefs, knowledge and instructional practices.

\section{Research Goals}

Two research goals drove this investigation. First, in an effort to better understand the "engineering teaching culture" at the high school level, we set out to measure pre-college STEM teachers' beliefs about engineering education. As noted, we chose to do this in the context of a specific, representative program, PLTW, because of its wide use nationally and its reputation for achieving rigor in STEM education ${ }^{1}$. Second, we wanted to measure the combined impact of the PLTW professional development training and the initial PLTW teaching experience had on teachers' beliefs. To meet these goals we first measured teachers' baseline views in order to document the inherent differences that may exist among STEM teachers even before they formally diverge to these distinct programs. We then re-administered the beliefs survey to STEM teachers who did and who did not participate in the training program and go on to actually teach a PLTW course. Together this approach led to a 2 factor (time 1 v. time 2) by 2 factor (summer institute, SI v. control, CO) quasi-experimental design ${ }^{24}$ that examined changes in pre- and postintervention survey responses for SI teachers above and beyond changes exhibited by those who did not elect to train and teach a course within the time period of the study.

\section{Methods}

Participants in the initial administration of the EEBEI-T survey were high school science, mathematics and technical education teachers $(\mathrm{N}=182$; see Table 1 for the population breakdown). Teachers were recruited by email through state departments of instruction and the 
PLTW affiliate colleges. Most respondents were white (95.9\%) and male (59.8\%). None of the teachers had taught PLTW at the time of the first survey administration or taken part in the PLTW teacher summer institute training. During summer 2008 some of the teachers $(\mathrm{N}=82)$ attended a mandatory PLTW summer institute (SI) and became initially certified to teach PLTW engineering courses. The remaining control $(\mathrm{CO})$ teachers $(\mathrm{N}=100)$ provided control for the SI effects measured in survey re-testing. Teachers were surveyed again in January 2009 to document changes in their views and expectations due to the SI training and one semester of PLTW teaching. At re-test, 36 SI teachers and 41 CO teachers completed the second survey. This design allowed us to track both initial differences in the beliefs and expectations among teachers with different teaching assignments, and to document the effects that pre-engineering professional development had on newly-minted PLTW teachers, controlling for effects of survey retesting and time.

Table 1. Teacher demographics overall and by comparison groups.

\begin{tabular}{|c|c|c|c|}
\hline & OVERALL & Control & SI \\
\hline No. Years Teaching & $N=174$ & $N=96$ & $N=78$ \\
\hline $0-3$ & $15.52 \%$ & $11.46 \%$ & $20.51 \%$ \\
\hline $4-10$ & $24.71 \%$ & $22.92 \%$ & $26.92 \%$ \\
\hline $11-20$ & $36.20 \%$ & $38.54 \%$ & $33.33 \%$ \\
\hline $20+$ & $23.56 \%$ & $27.08 \%$ & $19.23 \%$ \\
\hline Highest Degree & $\mathbf{N}=173$ & $N=96$ & $\mathbf{N}=77$ \\
\hline $\mathrm{BA}$ & $36.42 \%$ & $32.29 \%$ & $41.56 \%$ \\
\hline MA & $61.85 \%$ & $66.67 \%$ & $55.84 \%$ \\
\hline $\mathrm{PhD}$ & $1.73 \%$ & $1.04 \%$ & $2.60 \%$ \\
\hline Gender & $N=174$ & $N=96$ & $\mathbf{N}=78$ \\
\hline Male & $59.77 \%$ & $48.96 \%$ & $73.08 \%$ \\
\hline Female & $40.23 \%$ & $51.04 \%$ & $26.92 \%$ \\
\hline Race/Ethnicity & $N=169$ & $\mathbf{N}=92$ & $\mathbf{N}=77$ \\
\hline White/Caucasian & $95.86 \%$ & $98.91 \%$ & $92.21 \%$ \\
\hline African-American & $2.96 \%$ & --- & $6.49 \%$ \\
\hline Hispanic & --- & --- & --- \\
\hline Other & $1.19 \%$ & $1.09 \%$ & $1.30 \%$ \\
\hline
\end{tabular}

The survey was administered online in the spring to all participants, using a secure system provided by the University of Wisconsin. Participants read through and agreed to an IRB approved consent statement, following federal guidelines for working with human subjects. All participants were offered $\$ 10$ in compensation for their efforts. 
The EEBEI-T survey ${ }^{16}$ was made up of 42 Likert scale items across seven previously tested constructs, along with 16 demographic questions. Below are two example survey items. A 5point Likert scale (with a midpoint of 3) was used to rate teachers' beliefs about the frequency of occurrence of the events stated in some survey items. Item 8 a shows a statement followed by the 5 choices, with the verbal anchors for each frequency scale score shown in parentheses.

8a. The math content being taught in my courses is explicitly connected to engineering.

1 (Never) 2 (Almost Never) 3 (Sometimes) 4 (Often) 5 (Almost Always)

A 7-point Likert scale (with a midpoint of 4) was used for rating teachers' levels of agreement with statements. Item 6a shows a statement followed by the 7 choices, with the verbal anchors for each agreement scale score shown in parentheses:

6a. To be an engineer a student must have high overall academic achievement.

1 (Strongly disagree) 2 (Disagree) 3 (Somewhat disagree)

4 (Neutral) 5 (Somewhat agree) 6 (Agree) 7 (Strongly agree)

Teachers visited a supplied web link and, after giving consent for the study, selected the "radio button" that best matched the degree to which each statement matched their own views. The online system ensured that only given choices were selected (no intermediate values were possible). Because space on a page was not a factor for the on-line presentation, every item was accompanied by the complete set of verbal anchors for every numerical rating choice, minimizing errors due to forgetting or reversing of the scales.

Inclusion of the $\mathrm{CO}$ group along with retesting of teachers' attitudes the following winter allowed us to examine the changes in teachers' views when controlling for two important influences. First, CO and SI teachers started out with some significant differences in their beliefs and expectations about engineering. The baseline comparisons between the $\mathrm{CO}$ and SI group made these initial differences apparent. It also clarifies hat there is likely to be some selection bias between the samples, since teachers largely self-select for PLTW instruction. Since we are not in a position to experimentally randomize becoming a PLTW instructor (this is a professional choice made by each instructor working within a particular school system), the group differences at baseline allow us to control for these inherent differences. Second, if changes in views occur over time, as teachers mature, historical events unfold that influence attitudes about engineering (such as the release of the Grand Challenges ${ }^{25}$ ), or simply as a result of retesting, these changes can also be statistically controlled.

\section{Results}

In this section we report and interpret the mean survey ratings that teachers gave in the initial survey administration during the spring of $2008(\mathrm{~N}=182)$, before teaching a PLTW course.

\section{Teachers' initial beliefs and expectations about engineering preparation}

Table 2 summarizes the seven constructs that were central to our study. The titles and verbal interpretation shown for each construct are inferred and did not appear anywhere on the survey, but are meant to help the reader understand the overall meaning conveyed across the range of 
items given. In addition, we show the total number of final items, followed by whether it was a 5-point or 7-point rating scale.

Constructs A, B, F, \& G (5-point scale) assessed teachers' ratings of the frequency with which these conditions occurred. Mean ratings for Constructs A \& F exceeded the midpoint of the scale, while ratings for Construct $\mathrm{G}$ were, on average, below the midpoint. Constructs $\mathrm{C}, \mathrm{D}, \& \mathrm{E}$ (7-point scale) assessed teachers' levels of agreement. Mean ratings of Constructs C, D and E exceed the mid-point. For example, Construct D shows teachers generally believe high academic performance in math, science and technology courses is pre-requisite to a career in engineering.

To account for the indirect nature of survey measures and their inherent subjectivity, we performed internal consistency reliability analyses on the survey constructs using Cronbach's alpha $(\alpha)$, a measure that varies between 0 and $1.0^{26}$. The reliability analysis suggests that the EEBEI-T is a well-designed instrument (Table 2; $\mathrm{N}=182$ ). Mean ratings of each construct are near the center value for each scale, indicating that responses to these constructs are not statistically skewed. The estimated values for Cronbach's alpha are above .70, indicating a high reliability estimate ${ }^{27}$.

Table 2. Summary of means and construct reliability parameters for EEBEI-T survey administration before a subsample of teachers taught PLTW courses for the first time.

\begin{tabular}{|c|c|c|c|c|}
\hline \multicolumn{3}{|l|}{ Applicable to All Surveys } & \multicolumn{2}{|c|}{$\begin{array}{l}\text { Survey \#1 } \\
\text { June } 2008 \\
(\mathrm{~N}=182)\end{array}$} \\
\hline Construct Title and Interpretation & $\begin{array}{l}\text { No. } \\
\text { Items }\end{array}$ & $\begin{array}{l}\text { Scale } \\
{[\mathrm{Mid}]}\end{array}$ & Mean & $\alpha$ \\
\hline $\begin{array}{l}\text { A. Influences on Instruction: Students' Academic } \\
\text { Abilities. My lessons are influenced by students' academic } \\
\text { performance. }\end{array}$ & 5 & $\begin{array}{l}1-5 \\
{[3]}\end{array}$ & 3.11 & 0.72 \\
\hline $\begin{array}{l}\text { B. Influences on Instruction: Students' Backgrounds and } \\
\text { Interests. I integrate students' interests and cultural } \\
\text { backgrounds into classroom activities. }\end{array}$ & 7 & $\begin{array}{l}1-5 \\
{[3]}\end{array}$ & 3.01 & 0.78 \\
\hline $\begin{array}{l}\text { C. Beliefs and Knowledge about Student Out-of-School } \\
\text { Activities. Students' science / math / technical learning } \\
\text { takes place in the home and community. }\end{array}$ & 5 & $\begin{array}{l}1-7 \\
{[4]}\end{array}$ & 5.70 & 0.79 \\
\hline $\begin{array}{l}\text { D. Careers in Engineering: Academic Achievement. To be } \\
\text { an engineer a student must have high academic } \\
\text { achievement in math, science and technology courses. }\end{array}$ & 6 & $\begin{array}{l}1-7 \\
{[4]}\end{array}$ & 4.86 & 0.79 \\
\hline $\begin{array}{l}\text { E. Careers in Engineering: Social Network/Background. } \\
\text { The student whose parent is an engineer, who is male, and } \\
\text { either white or Asian, is most likely to pursue engineering. }\end{array}$ & 8 & $\begin{array}{l}1-7 \\
{[4]}\end{array}$ & 4.35 & 0.80 \\
\hline $\begin{array}{l}\text { F. Teaching for Engineering: Academic Courses. The } \\
\text { science and math content taught in my courses is explicitly } \\
\text { connected to engineering. }\end{array}$ & 3 & $\begin{array}{l}1-5 \\
{[3]}\end{array}$ & 3.23 & 0.91 \\
\hline
\end{tabular}




\begin{tabular}{|l|c|c|l|l|}
\hline $\begin{array}{l}\text { G. Environmental and Structural Support. My school } \\
\text { provides resources for students interested in engineering } \\
\text { (e.g., internships, professional development opportunities). }\end{array}$ & 8 & $\begin{array}{r}1-5 \\
{[3]}\end{array}$ & 2.81 & 0.79 \\
\hline
\end{tabular}

\section{Differences in teachers' initial beliefs and expectations about engineering preparation}

For most of the Constructs (A, B, C, E, see Table 3), the differences between the PLTW and the $\mathrm{CO}$ groups were not statistically significant. This suggests that although these teachers have different professional training and instructional emphases, they express the views of the group as a whole, as summarized above. However, the results show that the EEBEI-T exposes differences in teacher views for some constructs. Specifically, three constructs were found to be statistically different $(\alpha=.05)$ when comparing group means.

$\mathrm{CO}$ teachers were less likely to identify sources of support for engineering in their schools (Construct $\mathrm{G}$ ) than future SI teachers. This result, while interesting, may simply be due to differences in the resources actually offered by schools with lesser and greater commitments to technical education and school-to-work transition programs. It is logical, for example, to imagine that those striving to teach PLTW in the future come from institutions that already have a commitment to pre-college engineering.

Table 3. Differences in mean ratings between teachers prior to summer institute $(\mathrm{N}=182)$.

\begin{tabular}{|l|r|r|r|r|r|r|}
\hline & \multicolumn{2}{|c|}{$\begin{array}{c}\text { CO } \\
(\mathrm{N}=100)\end{array}$} & \multicolumn{2}{c|}{$\begin{array}{c}\text { SI } \\
(\mathrm{N}=82)\end{array}$} & \multicolumn{2}{c|}{$\begin{array}{c}\text { Results From Independent } \\
\text { Samples t-Tests }\end{array}$} \\
\hline \multicolumn{1}{|c|}{ Construct } & Mean & $\begin{array}{c}\text { Std. } \\
\text { Dev. }\end{array}$ & Mean & $\begin{array}{c}\text { Std. } \\
\text { Dev. }\end{array}$ & t & p-value \\
\hline $\begin{array}{l}\text { A. Influences on Instruction: Students' } \\
\text { Academic Abilities }\end{array}$ & 3.04 & .516 & 3.19 & .618 & -1.788 & .075 \\
\hline $\begin{array}{l}\text { B. Influences on Instruction: Students' } \\
\text { Backgrounds and Interests }\end{array}$ & 2.97 & .597 & 3.06 & .541 & -1.038 & .300 \\
\hline $\begin{array}{l}\text { C. Beliefs and Knowledge about Student Out-of- } \\
\text { School Activities }\end{array}$ & 5.64 & .796 & 5.78 & .720 & -1.275 & .204 \\
\hline $\begin{array}{l}\text { D. Careers in Engineering: Academic } \\
\text { Achievement }\end{array}$ & 5.02 & .960 & 4.66 & .890 & 2.612 & $.01^{*}$ \\
\hline $\begin{array}{l}\text { E. Careers in Engineering: Social } \\
\text { Network/Background }\end{array}$ & 4.3 & .782 & 4.42 & .903 & -.976 & .330 \\
\hline $\begin{array}{l}\text { F. Teaching for Engineering: Integration of } \\
\text { Academic Concepts and Engineering }\end{array}$ & 2.87 & .909 & 3.67 & .912 & -5.936 & $.000^{*}$ \\
\hline G. Environmental and Structural Support & 2.60 & .760 & 3.07 & .807 & -4.029 & $.000^{*}$ \\
\hline
\end{tabular}

$* \mathrm{p}<.05$.

We found that CO teachers agreed more strongly than future SI teachers that to be successful, an engineer needs to demonstrate high scholastic achievement in math, science and technology $($ Construct D), $t(180)=2.612, p=.010$. Here we see that teachers of math and science courses, which often serve a college preparatory function rather than providing technical skills, see excellence in academic performance as a kind of gatekeeper for engineering. This finding replicates previous results showing differences among high school teachers ${ }^{16}$. 
Even before teaching PLTW courses, SI teachers were more likely than CO teachers to claim that science and math content taught in their classes was integrated with engineering content $($ Construct F), $t(180)=-5.936, p<.001$.

\section{Changes in teachers' initial beliefs and expectations about engineering preparation}

A second administration of the EEBEI-T was given in January 2009. Out of the original sample, 77 teachers responded to the invitation to take the second survey, including 36 SI teachers, and $41 \mathrm{CO}$ teachers who served as our control subjects. It should be noted that those in the SI group were high school science, math and technical education teachers who, like the control group, had not previously taught in the PLTW program before this study.

By January, the main divergence between the groups was that SI teachers attended the two-week PLTW summer training institute and then went on to teach PLTW in their high schools.

Administering the second survey the following winter allowed us to investigate changes in teacher views once the new PLTW teachers applied the concepts and skills learned during the summer institute to their classrooms. Since significant psychological traits do not easily change (e.g., over merely two weeks) it was decided this was a more authentic way to measure the impact of new PLTW instruction on teachers' views.

Because of the reduced response rate for the second survey administration, comparisons between groups and from June 2008 to January 2009 are now presented exclusively for only those teachers who provided complete data at both points in time. Comparisons (summarized in Table 4) show change data for $\mathrm{CO}$ teachers $(\mathrm{N}=41)$ and for SI teachers $(\mathrm{N}=36)$.

As reported on the baseline survey, $\mathrm{CO}$ teachers were more likely than SI teachers to believe that high academic achievement in science, math and technology courses was necessary to become an engineer (Construct D), and this group difference showed no change over time. We also learned that teachers in both groups initially reported that they did not strongly address students' interests and cultural backgrounds when designing classroom instruction (Construct B). At re-test, regardless of PLTW training, teachers reported attending to student background and interest less than they reported at time $1, F(1,75)=4.04, p=.048$, essentially adopting a less constructivist attitude toward student learning.

SI teachers started out more positive about the institutional support they experienced for engineering at their schools (Construct $\mathrm{G}$ ) than control teachers, and this difference grew significantly over time. Statistically, we found a significant main effect of group $F_{\text {Group }}(1,75)=$ $20.96, p<.001$ (SI higher than CO), a significant main effect for time, $F_{\text {Time }}(1,75)=4.154, p=$ .045 , and a significant group X time interaction, $F_{\text {GroupXTime }}(1,75)=6.24, p=.015$. Analysis of the specific responses showed that while $\mathrm{CO}$ teachers remained essentially constant in their views, SI teacher showed a marked increase after the training and teaching experiences.

Finally, SI teachers believed more strongly than MS teachers that the math and science concepts taught in their courses were explicitly connected to engineering (Construct $\mathrm{F}$ ), $F(1,75)=34.45$, $p<.001$. The re-testing of beliefs showed that for this sample of teacher this gap grew, due both 
to stronger agreement among SI teachers and stronger disagreement among $\mathrm{CO}$ teachers over time, $F(1,75)=15.78, p<.001$.

Table 4. Means and standard deviations of construct scores for those control $(\mathrm{CO}, \mathrm{N}=41)$ and summer institute ( $\mathrm{SI}, \mathrm{N}=36$ ) teachers who participated in both spring 2008 and January 2009 survey administrations.

\begin{tabular}{|c|c|c|c|c|c|c|c|c|}
\hline \multirow{3}{*}{ Construct } & \multicolumn{4}{|c|}{$\begin{array}{c}\mathrm{CO} \\
(\mathrm{N}=41)\end{array}$} & \multicolumn{4}{|c|}{$\begin{array}{c}\text { SI } \\
(\mathrm{N}=36)\end{array}$} \\
\hline & \multicolumn{2}{|c|}{ Test1 } & \multicolumn{2}{|c|}{ Test2 } & \multicolumn{2}{|c|}{ Test1 } & \multicolumn{2}{|c|}{ Test2 } \\
\hline & Mean & St. Dev. & Mean & St. Dev. & Mean & St. Dev. & Mean & St. Dev \\
\hline $\begin{array}{l}\text { A. Influences on Instruction: } \\
\text { Students' Academic } \\
\text { Abilities }\end{array}$ & 3.03 & .493 & 3.09 & .473 & 3.11 & .531 & 3.21 & .445 \\
\hline $\begin{array}{l}\text { B. Influences on Instruction: } \\
\text { Students' Backgrounds and } \\
\text { Interests }\end{array}$ & 3.06 & .594 & 2.91 & .547 & 2.95 & .464 & 2.86 & .507 \\
\hline $\begin{array}{l}\text { C. Beliefs and Knowledge } \\
\text { about Student Out-of- } \\
\text { School Activities }\end{array}$ & 5.64 & .616 & 5.61 & .686 & 5.82 & .743 & 5.64 & .862 \\
\hline $\begin{array}{l}\text { D. Careers in Engineering: } \\
\text { Academic Achievement }\end{array}$ & 5.10 & .816 & 5.02 & .783 & 4.75 & .962 & 4.53 & .892 \\
\hline $\begin{array}{l}\text { E. Careers in Engineering: } \\
\text { Social } \\
\text { Network/Background }\end{array}$ & 4.25 & .688 & 4.39 & .707 & 4.58 & .796 & 4.55 & .726 \\
\hline $\begin{array}{l}\text { F. Teaching for Engineering: } \\
\text { Integrating Engineering } \\
\text { with Academic Courses }\end{array}$ & 3.02 & .830 & 2.76 & .778 & 3.61 & .885 & 4.08 & .798 \\
\hline $\begin{array}{l}\text { G. Environmental and } \\
\text { Structural Support }\end{array}$ & 2.55 & .752 & 2.52 & .773 & 3.15 & .806 & 3.42 & .716 \\
\hline
\end{tabular}

\section{Summary of Findings}

Previous educational research indicated that instructional practices and teacher decision-making processes are influenced by teachers' beliefs and expectations about student learning and about teachers' own instructional practices. To effect meaningful and sustainable change to engineering education, knowledge of teachers' beliefs and expectations will need to be rigorously documented so that policies and programs for teacher education and professional development can be developed based on a sound empirical foundation. This study presented results obtained using a statistically reliable survey instrument that documents changes in high school teachers' beliefs and expectations about pre-college engineering instruction and student preparation for future success in college engineering programs and careers in engineering as a result of their early participation in the PLTW program. We used baseline data on teachers' views and a control group of teachers who did not teach engineering courses as sources of comparisons to better interpret these data.

We found that teachers choosing to teach pre-college engineering already exhibit some different views about engineering learning and instruction than STEM teachers in the control group. 
Specifically, budding PLTW SI teachers were more likely than control teachers to: identify sources of support for engineering in their schools, to report that science and math concepts were integrated with engineering activities during their instruction; and to disagree that to be an engineer one must demonstrate high scholastic achievement in math, science and technology.

Teachers also exhibited some changes from the initial survey in the spring of 2008 to the second survey given in January 2009. Generally, teachers from both groups reported being less inclined to use students' interests and backgrounds to shape classroom instruction. Regardless of their specific programs, teachers are adopting a less constructivist approach toward student learning, perhaps because of the growing pressures regarding high stakes assessments in a system that demands teacher and school accountability of student progress. ${ }^{29}$

We were also able to identify changes in teachers' views due to PLTW training and teaching above and beyond pre-existing group differences and changes that naturally occurred over time, as a result of re-testing and any other intervening historical events (e.g., a focus on STEM education during the 2008 Presidential election). The primary change attributable specifically to PLTW training and teaching is an increased belief among SI teachers that they are providing instruction to their students that effectively integrates science and math concepts with engineering activities. This is an important area of change for several reasons. First, there is a growing recognition of the need to teach STEM content in an integrated manner, and several federal and state policy initiatives are advocating this integration across the grade levels. If the professional development programs sponsored by PLTW are effective at fostering greater integration, this is a valuable outcome. Second, a number of recent research studies have examined engineering curricula and classroom instruction in order to determine the extent to which academic and technical subjects are integrated ${ }^{18}$, and the resulting impact this has on student achievement in science and math $^{30}$ (Phelps, Camburn, \& Durham, 2009). Finally, engineering education reform has begun to recognize the importance of teachers as agents for informing and implementing educational reform, and the key role that professional development can play toward these goals. Each of these issues is taken up in the next section.

\section{Discussion and Conclusions}

\section{Research methodology}

Investigation of the impact of education programs on a select group of participants are an inherently challenging enterprise. It is often the case that assignment is not under the researcher's control, but determined by the participants themselves, perhaps in consultation with parents, teachers and others. Consider the make up of students who select to enroll in pre-college engineering classes. To deny (or even delay) access to suit research faces serious ethical barriers, since it denies students and parents their preferences, and could impose serious damage to their scholastic progress and even later academic and workplace opportunities. In a somewhat similar manner, teachers opt to participate in or avoid engineering instruction and manipulating this selection for research purposes faces serious professional and ethic issues. With limited ability in public schools to assign teachers to their classes, there is a need to document inherent differences that may exist among teachers and to interpret the impact of training and teaching experiences within the context of pre-existing differences. 
Quasi-experimental design research methodology may not be considered to be the "gold standard" by every deliberating body ${ }^{31-33}$, but it is a highly effective method for addressing many of the practical constraints within authentic educational settings.

\section{Educational Implications and Persistent Challenges for Implementing Reform}

Along with a growing urgency for promoting STEM education has come a drive to reconceptualize the contributing areas of science, technology, engineering and mathematics in an integrated fashion ${ }^{18}$. This comes in part from several highly visible initiatives ${ }^{1,34,36}$. Commercial curricula such as PLTW have emerged to satisfy this mandate toward STEM integration ${ }^{35}$. It is notable, then, that our main finding is that the PLTW teacher training program accompanied with classroom instruction instills in new PLTW teachers a greater sense that they are addressing this mandate by providing instruction that more frequently integrates concepts from math and science into the engineering activities in their classrooms. By encouraging the integrative outlook on engineering instruction, PLTW engineering students are expected to make the conceptual connections needed to ground their academic knowledge to real world applications, while at the same time developing a greater understanding of how the specific ideas and procedures that they encounter in an engineering context will be generalized to new problems and application areas.

In this light, it is critical to acknowledge both the difficulties and promising approaches for achieving the integration of concepts from science and math with engineering instruction in a manner that influences student thinking. Some of the documented difficulties have come about through recent investigations of engineering curricula, classroom instruction and student achievement $\mathrm{t}^{23,37,39,40,41,44}$. A recent study from the National Academy of Engineering ${ }^{18}$, Engineering in K-12 Education: Understanding the Status and Improving the Prospect reported that integration between engineering and the core content areas, while laudable, is quite rare. On the other hand, there have been notable efforts toward STEM integration ${ }^{42,43}$. Schunn ${ }^{44}$ argued that STEM education implies an integrative curriculum that reveals a synergy beyond the constituent parts. He notes that several workable methods can enhance the level of integration, such as using the new topics and contexts to reinforce mathematical understanding and application.

The teacher training developed by PLTW appears to contribute to an understanding of the importance of taking an integrative perspective on engineering education that may serve central policy goals, such as the Perkins mandate to allow "students to achieve both academic and occupational competencies." 34

\section{Funding Acknowledgement}

This work was funded by a grant from the National Science Foundation \# EEC-0648267, entitled "Aligning Educational Experiences with Ways of Knowing Engineering (AWAKEN)" to the University of Wisconsin-Madison. 


\section{Bibliography}

${ }^{1}$ NRC. 2007. Rising Above The Gathering Storm: Energizing and Employing America for a Brighter Economic Future Committee on Prospering in the Global Economy of the 21st Century: An Agenda for American Science and Technology, Washington, DC: National Academy of Sciences, National Academy of Engineering, Institute of Medicine, National Academy Press.

${ }^{2}$ www.ed.gov/programs/racetothetop

${ }^{3}$ Fink, L. D., Ambrose, S. \& Wheeler, D. (2005). Becoming a professional engineering educator: A new role for a new era. Journal of Engineering Education, 94(1), 185-194.

${ }^{4}$ Brophy, J. E., \& Good, T. L. (1974). Teachers' communication of differential expectations for children's classroom performance: Some behavioral data. Journal of Educational Psychology, 61, 365-374.

${ }^{5}$ Borko, H., Livingston, C. \& Shavelson, R. J. (1990). Teachers' thinking about instruction. Remedial and Special Education, 11(6), 40-49.

${ }^{6}$ Grossman, P. (1990). The making of a teacher: Teacher knowledge and teacher education. New York: Teachers College Press.

${ }^{7}$ Nathan, M. J., \& Koedinger, K. R. (2000). An investigation of teachers' beliefs of students' algebra development. Cognition and Instruction, 18(2), 207-235.

${ }^{8}$ Rosenthal R. \& Jacobson, L. (1968). Pygmalion in the classroom: Teacher expectations and pupils' intellectual development. New York: Holt, Rinehart \& Winston.

${ }^{9}$ Leinhardt, G., \& Greeno, J. G. (1986). The cognitive skill of teaching. Journal of Educational Psychology, 78(2), 75-95.

${ }^{10}$ Nye, B., Konstantopoulos, S., \& Hedges, L. V. (2004). How large are teacher effects? Educational Evaluation and Policy Analysis, 26(3), 237-257.

${ }^{11}$ Rowan, B. (2004). Teachers matter: Evidence from value-added assessments. AERA Research Points: Essential Information for Educational Policy, 2(2), 1-4. http://www.aera.net/ Retrieved on Nov. 10, 2009.

${ }^{12}$ Custer, R. L. \& Daugherty, J. L. (2009). Professional Development for Teachers of Engineering: Research and Related Activities, 29(3). Washington, DC: National Academic of Engineering. http://www.nae.edu/Publications/TheBridge/16145/16204.aspx Accessed on Nov.10, 2009.

${ }^{13}$ Yasar, S., Baker, D., Robinson-Kurpius, S., Krause, S. \& Roberts, C. (2006). Development of a survey to assess K-12 teachers' perceptions of engineers and familiarity with teaching design, engineering, and technology. Journal of Engineering Education, 95(3), 205-216.

${ }^{14}$ Shulman, L. (2005). If Not Now, When? The Timeliness of Scholarship of the Education of Engineers. Journal of Engineering Education, 94(1), 11-12.

${ }^{15}$ Anonymous (2006). The research agenda for the new discipline of engineering education. Journal of Engineering Education, 95(4), 259-261.

${ }^{16}$ Nathan, M. J., Tran, N., Atwood, A. K., Prevost, A., \& Phelps, L. A. (2009). High school teachers' beliefs about engineering preparation. Proceedings of the American Society of Engineering Education (ASEE) 2009 (Paper no. AC 2009-1715, pp. 1-20.) Austin, TX: ASEE Publications.

${ }^{17}$ Cronbach, L. J. (1971). Test validation. In R. L. Thorndike (Ed.). Educational Measurement (2nd Ed.). Washington, D. C.: American Council on Education.

${ }^{18}$ Katehi, L., Pearson, G. \& Feder, M. (Eds.) (2009). Engineering in K-12 education: Understanding the status and improving the prospects. Washington, D.C.: The National Academies Press,

${ }^{19}$ Walcerz, D. (2007). Report on the Third Year of Implementation of the TrueOutcomes Assessment System for Project Lead The Way. http://www.pltw.org/pdfs/AnnualReport-2007-Public-Release.pdf

${ }^{20}$ PLTW (2004). http://www.pltw.org/Engineering/Curriculum/sample-schedule.cfm, accessed 02/02/09

${ }^{21}$ Project Lead The Way. http://www.pltw.org/index.cfm.

${ }^{22}$ Darling-Hammond, L., Chung Wei, R., Andree, A, Richardson, N., \& Orphanos, S. (2009). Professional learning in the learning profession: A status report on teacher development in the United States and abroad. Dallas, TX: National Staff Development Council.

${ }^{23}$ Prevost, A., Nathan, M. J., Stein, B., Tran, N., \& Phelps, L. A. (2009). Integration of mathematics in pre-college engineering: The search for explicit connections. Proceedings of the American Society of Engineering Education (ASEE) 2009 (Paper no. AC 2009-1790, pp. 1-27.) Austin, TX: ASEE Publications.

${ }^{24}$ Shadish, W.R., Cook, T.D. \& Campbell, D.T. (2002). Experimental and Quasi-Experimental Designs for Generalized Causal Inference. New York: Houghton Mifflin Company.

${ }^{25}$ www.engineeringchallenges.org 
${ }^{26}$ Cronbach, L. J. (1951). Coefficient alpha and the internal structure of tests. Psychometrika, 16(3), 297-334.

${ }^{27}$ Black, T.R. (1999). Doing quantitative research in the social sciences: An integrated approach to research design, measurement, and statistics. London: Sage.

${ }^{28}$ Nathan, M. J., Tran, N., Atwood, A., Prevost, A., \& Phelps, L. A. (under revision). Beliefs and expectations about engineering preparation exhibited by high school science, mathematics and technical education teachers.

${ }^{29}$ Neill, M. (2003). Leaving Children Behind: How No Child Left Behind Will Fail Our Children. Phi Delta Kappan, November 2003, pp. 225-28.

${ }^{30}$ Phelps, L.A., Camburn, E., \& Durham, J. (2009, June). Engineering the math performance gap. Research Brief. Madison: Center on Education and Work, University of Wisconsin-Madison.

${ }^{31}$ Cook, T. D., Shadish, W. R., \& Wong, V. C. (2008), Three Conditions Under Which Experiments and Observational Studies Produce Comparable Causal Estimates: New Findings From Within-Study Comparisons. Journal of Policy Analysis and Management, 27, 724-750.

${ }^{32}$ Shavelson, R. J. \& Towne, L. (2002). Scientific Research in Education. Committee on Scientific Principles for Education Research. Washington, DC: National Research Council.

${ }^{33}$ U. S. Department of Education Institute of Education Sciences. (2003). Identifying and Implementing Educational Practices Supported by Rigorous Evidence: A User Friendly Guide.

${ }^{34}$ Public Law 105-332, 1998, http://www.cccs.edu/Docs/SBCCOE/PerkinsAct1998.pdf (last accessed March 2009)

${ }^{35}$ PLTW (2009). From http://www.pltw.org/ Engineering/Curriculum/Curriculum-high-school.cfm accessed on $1 / 13 / 09$.

${ }^{36}$ Chang, K. (2009). White House Begins Campaign to Promote Science and Math Education (Published: November 23, 2009). http://www.nytimes.com/2009/11/24/science/24educ.html Last accessed on Dec. 12, 2009

${ }^{37}$ Nathan, M. J., N. Tran, L. A. Phelps, and A. Prevost. 2008. The structure of high school academic and preengineering curricula: Mathematics. In Proceedings of the American Society of Engineering Education Annual Conference and Exposition. Pittsburgh, PA.

${ }^{38}$ National Council of Teachers of Mathematics. 2000. Principles and standards for school mathematics. Reston, VA: Author.

${ }^{39}$ Nathan, M. J., Oliver, K., Prevost, A., Tran, N., \& Phelps, L. A. (2009). Classroom learning and instruction in high school pre-college engineering settings: A video-based analysis. Proceedings of the American Society of Engineering Education (ASEE) 2009 (Paper no. AC 2009-1577, pp. 1-23.) Austin, TX: ASEE Publications.

${ }^{40}$ Bottoms, G., \& Uhn, J. (2007). Project Lead the Way works: A new type of career and technical program. Southern Educational Review Board.

${ }^{41}$ Tran, N. \& Nathan, M. J. (in press). An investigation of the relationship between pre-college engineering studies and student achievement in science and mathematics. Journal of Engineering Education.

${ }^{42}$ Stone, J.R., Alfeld, C., \& Pearson, D. (2008). Rigor and relevance: Enhancing high school students' math skills through career and technical education. American Educational Research Journal, 45(3), 767-795.

${ }^{43}$ Moore, T.J. (2008). Model-Eliciting Activities: A case-based approach for getting students interested in material science and engineering. Journal of Materials Education, 30(5-6), 295 - 310. Published on the National Science Foundation's National Science Digital Library (NSDL) in the Materials Digital Library (MatDL) accessed at http://matdl.org/jme. Also see Moore, T.J., Roehrig, G.H., Lesh, R.A., \& Guzey, S.S. (in review). New directions for STEM integration research on what it means to "understand" concepts and abilities needed for success beyond school in the 21 st century.

${ }^{44}$ Schunn, C. (2009, March). What need to be put back into S, T, and E? Well chosen M. Presentation to the. Middle School Math Infusion STEM Symposium, Singer Island, Fl. NSF/Hofstra CTL Middle School Grades Math Infusion in STEM Symposium: Author. 